\title{
Impact of Pressure and Brine Salinity on Capillary Pressure-Water Saturation Relations in Geological $\mathrm{CO}_{2}$ Sequestration
}

\author{
Jongwon Jung ${ }^{1}$ and Jong Wan $\mathrm{Hu}^{2,3}$ \\ ${ }^{1}$ Department of Civil and Environmental Engineering, Louisiana State University, Baton Rouge, LA 70803, USA \\ ${ }^{2}$ Department of Civil and Environmental Engineering, Incheon National University, Incheon 406110, Republic of Korea \\ ${ }^{3}$ Incheon Disaster Prevention Research Center, Incheon National University, Incheon 406110, Republic of Korea \\ Correspondence should be addressed to Jongwon Jung; jjung@lsu.edu
}

Received 11 May 2016; Revised 21 July 2016; Accepted 31 July 2016

Academic Editor: Charles Rosenblatt

Copyright (C) 2016 J. Jung and J. W. Hu. This is an open access article distributed under the Creative Commons Attribution License, which permits unrestricted use, distribution, and reproduction in any medium, provided the original work is properly cited.

\begin{abstract}
Capillary pressure-water saturation relations are required to explore the $\mathrm{CO}_{2}$ /brine flows in deep saline aquifers including storage capacity, relative permeability of $\mathrm{CO}_{2}$ /brine, and change to stiffness and volume. The study on capillary pressure-water saturation curves has been conducted through experimentation and theoretical models. The results show that as the pressure increases up to $12 \mathrm{MPa}$, (1) capillary pressure-water saturation curves shift to lower values at given water saturation, (2) after the drainage process, residual water saturation decreases, and (3) after the imbibition process, capillary $\mathrm{CO}_{2}$ trapping increases. Capillary pressure-water saturation curves above $12 \mathrm{MPa}$ appear to be similar because of relatively constant contact angle and interfacial tension. Also, as brine salinity increases from $1 \mathrm{M}$ to $3 \mathrm{M} \mathrm{NaCl}$, (1) capillary pressure-water saturation curves shift to lower capillary pressure, (2) residual water saturation decreases, and (3) capillary $\mathrm{CO}_{2}$ trapping increases. The results show that pressure and brine salinity have an influence on the capillary pressure-water saturation curves. Also, the scaled capillary $\mathrm{CO}_{2}$ entry pressure considering contact angle and interfacial tension is inconsistent with atmospheric conditions due to the lack of wettability information. Better exploration of wettability alteration is required to predict capillary pressure-water saturation curves at various conditions that are relevant to geological $\mathrm{CO}_{2}$ sequestration.
\end{abstract}

\section{Introduction}

The demands for carbon-producing fossil fuels that have served the dominant energy resources for decades have been on the rise $[1,2]$. A growing discharge of carbon dioxide $\left(\mathrm{CO}_{2}\right)$ to atmosphere is anticipated. In order to reduce $\mathrm{CO}_{2}$ emission into the atmosphere, geological carbon sequestration (GCS) is required to store a large amount of $\mathrm{CO}_{2}$ in places such as depleted oil or gas reservoirs, coal seams, deep ocean sediments, and deep saline aquifers [3-5]. Among them, deep saline aquifers are the most promising area because of their large capacity reaching roughly 1,000 to $10,000 \mathrm{Gt}$ of $\mathrm{CO}_{2}$, which accounts for $99 \%$ of potential storage capacity in the world $[6,7]$.

$\mathrm{CO}_{2}$ flow and $\mathrm{CO}_{2}$-water displacement in deep saline aquifers depend on relation between capillary pressure $\left(P_{c}\right)$ and water saturation $\left(S_{w}\right)$ under reservoir conditions
[8-11]. This $P_{c}-S_{w}$ relationship is usually termed as capillary pressure-water saturation curve or soil-water characteristic curve which has relationships with soil properties such as storage capacity [12], relative permeability of $\mathrm{CO}_{2}$ /brine [1317], strength of soils [18-20], and changes to stiffness of soils [21-23].

Capillary pressure $\left(P_{c}\right)$ has been expressed as a function of relative water saturation $\left(S_{w}\right)$ using two most popular equations suggested by Brooks and Corey [24] (1) and van Genuchten [25] (2):

$$
\begin{aligned}
& P_{c}=P_{o}\left(\frac{S_{w}-S_{r}}{1-S_{r}}\right)^{-1 / \lambda}, \\
& P_{c}=P_{o}\left[\left(\frac{S_{w}-S_{r}}{1-S_{r}}\right)^{-1 / m}-1\right]^{1-m},
\end{aligned}
$$


where $S_{w}$ is the water saturation, $S_{r}$ is the residual water saturation, $P_{c}$ is the capillary pressure, $P_{o}$ is the capillary air (or gas) entry pressure, and $m$ and $\lambda$ are fitting parameters. With $m$ - and $\lambda$-values, both Brooks and Corey [24] and van Genuchten [25] models can be used to estimate the relative permeability of the fluids.

A capillary $\mathrm{CO}_{2}$ entry pressure $\left(P_{o}\right)$ between two phases $\left(\mathrm{CO}_{2}\right.$ and water) in porous media is important for both caprock system and reservoir, which are related to $\mathrm{CO}_{2}$ leakage from the underlying storage reservoir and $\mathrm{CO}_{2}$ injection to reservoir, respectively [26, 27]. A capillary $\mathrm{CO}_{2}$ entry pressure can be calculated using the following YoungLaplace equation:

$$
P_{o}=P_{\mathrm{CO}_{2}}-P_{\text {water }}=\frac{2 \sigma \cos \theta}{R},
$$

where $P_{\mathrm{CO}_{2}}$ is injected $\mathrm{CO}_{2}$ pressure, $P_{\text {water }}$ is the water pressure in reservoir, $\sigma$ is interfacial tension between $\mathrm{CO}_{2}$ and water, $\theta$ is water contact angle on mineral surface in water- $\mathrm{CO}_{2}$-mineral system, and $R$ is pore radius in porous media. Capillary $\mathrm{CO}_{2}$ entry pressure $P_{o}$ is estimated using the contact angle and the interfacial tension at various pressure-temperature conditions relating to geological $\mathrm{CO}_{2}$ sequestration (GCS) [26, 28-37]. Interfacial tension only varies within a small range of about $20-35 \mathrm{mN} / \mathrm{m}$ at the GCS relevant conditions [29, 33, 35], which has an influence slightly on the capillary $\mathrm{CO}_{2}$ entry pressure. Contact angle shows relatively huge changes within the range of 7-10 MPa pressure $[28-31,38]$, which has been explained through influential factors such as (1) the presence of the change of adsorbed water film thickness on mineral surface [39-41], (2) specific density of the function groups (silanol and silicic acid groups) on the mineral surface that influences the water film thickness or the hydrophilicity [42], and (3) $\mathrm{CO}_{2}$ reaction with hydroxyl groups on the mineral surface via hydrogen bonding [43]. For example, Jung and Wan [31] show that equilibrium contact angles on silica surface increase up to $17.6^{\circ} \pm 2.0^{\circ}$ along with increased pressure by reactions with supercritical $\mathrm{CO}_{2}\left(\mathrm{scCO}_{2}\right)$. Also, contact angles increase with brine salinity almost linearly with a net increase by $19.6^{\circ} \pm 2.1^{\circ}$ from deionized water to $5.0 \mathrm{M} \mathrm{NaCl}$ [31]. However, most of published contact angle results have shown significant discrepancies [27, 30, 36, 38, 44-51]. Thus, the role of surface reactions with $\mathrm{scCO}_{2}$ and the extent of their impact on mineral wettability remain elusive, making it difficult to estimate the capillary $\mathrm{CO}_{2}$ entry pressure using (3). Instead of (3), capillary pressure-water saturation curves for GCS have been determined during drainage and imbibition processes through laboratory experimentation that consider reservoir pressure and temperature conditions [46, 52-57]. The results in published data show the discrepancies due to the difficulties in accomplishing a full $\mathrm{CO}_{2}$-water saturation, controls of slight change to capillary pressure under a high-pressure system, and measurement of water saturation $[46,52-55,57]$. Recently, Tokunaga et al. [56] developed the experimental system to measure the capillary pressure-water saturation using hanging water column method at GCS relevant pressure and temperature conditions [56]. However, established capillary pressure curve is not able to cover a broad range of pressure, temperature, and chemical conditions including brine salinity effects which are relevant to GCS conditions. Thus, exploration of the capillary pressure curves at various pressure-temperature and brine salinity conditions relevant to geological $\mathrm{CO}_{2}$ sequestration (GCS) was conducted in this study.

\section{Experimental Study}

2.1. Materials. Uniformly round Ottawa sand 40/60 (number 40-60 mesh) as the representative of silica materials of which grain size was distributed between $250 \mu \mathrm{m}$ and $355 \mu \mathrm{m}$ was sieved. While Ottawa sand 40/60 used in this study has higher porosity than core samples in GCS sites, many contact angle data have been published for Ottawa sand 40/60 [31] that can be used to estimate the capillary $\mathrm{CO}_{2}$ entry pressure using (3) [please note that contact angle and interfacial tension effects on capillary pressure-water saturation curves were emphasized in this study; thus, contact angle and interfacial tension data are required]. The sand was wet-packed to a full saturation at $n=0.381$ in a chamber. Hydraulic conductivity with a separate sample of the sand (packed to the same porosity, $n=0.381$, and pore volume $=80.7 \mathrm{~cm}^{3}$ ) was $k=3.96 \times 10^{-4} \mathrm{~m} / \mathrm{s}$ (2.1 darcies) based on the constant head test. $1.0 \mathrm{M}$ and $3.0 \mathrm{M} \mathrm{NaCl}$ solutions were prepared for the aqueous phases to explore the brine salinity effects on capillary pressure-water saturation curves. Air and $\mathrm{CO}_{2}$ (Airgas, $99.99 \%$ purity) were used as nonaqueous phases.

2.2. Experimental Setup. Experimental system including a high-pressure chamber (inner diameter, ID $=8.21 \mathrm{~cm}$ and height $=4 \mathrm{~cm}$ ) was designed for capillary pressure-water saturation tests (Figure 1). A stainless steel porous plate with $1 \mu \mathrm{m}$ pore size $(3.0 \mathrm{~mm}$ thick and $79.7 \mathrm{~mm}$ diameter, Mott Corp.) was placed at the bottom in chamber and fully saturated-Ottawa sand pack was placed on porous plate in chamber. Another porous plate with a $50 \mu \mathrm{m}$ pore size (3.0 $\mathrm{mm}$ thick and $79.7 \mathrm{~mm}$ diameter, Mott Corp.) was placed on top of the sand pack. Fully saturated-sand was packed in chamber using wetting method. One-fifth of the chamber was filled with water and soils were dumped into the water, which was repeated five times to prepare for a fully saturated-sand pack.

Figure 1 shows the experimental setup for capillary pressure- $\left(P_{c^{-}}\right)$water saturation $\left(S_{w}\right)$ relation test. The hanging water column method was used $[60,61]$. The chamber was connected to vertically oriented transparent capillary pressure regulator. When capillary pressure regulator was moved downward, the capillary pressure $\left(P_{c}\right)$ was induced by head difference between the top and bottom of sand pack, which caused the water to flow out from the sand pack. Also, the transparent capillary pressure regulator served as a reservoir for measuring the outflow from the sand pack (volumes interpolated to $0.2 \mathrm{~mL}$ ). The top of the chamber and the upper end of the capillary pressure regulator were connected using a high-pressure tube, which maintained a closed system (Figure 1).

After saturating the sand pack, the water level in the capillary pressure regulator was equilibrated on surface of 


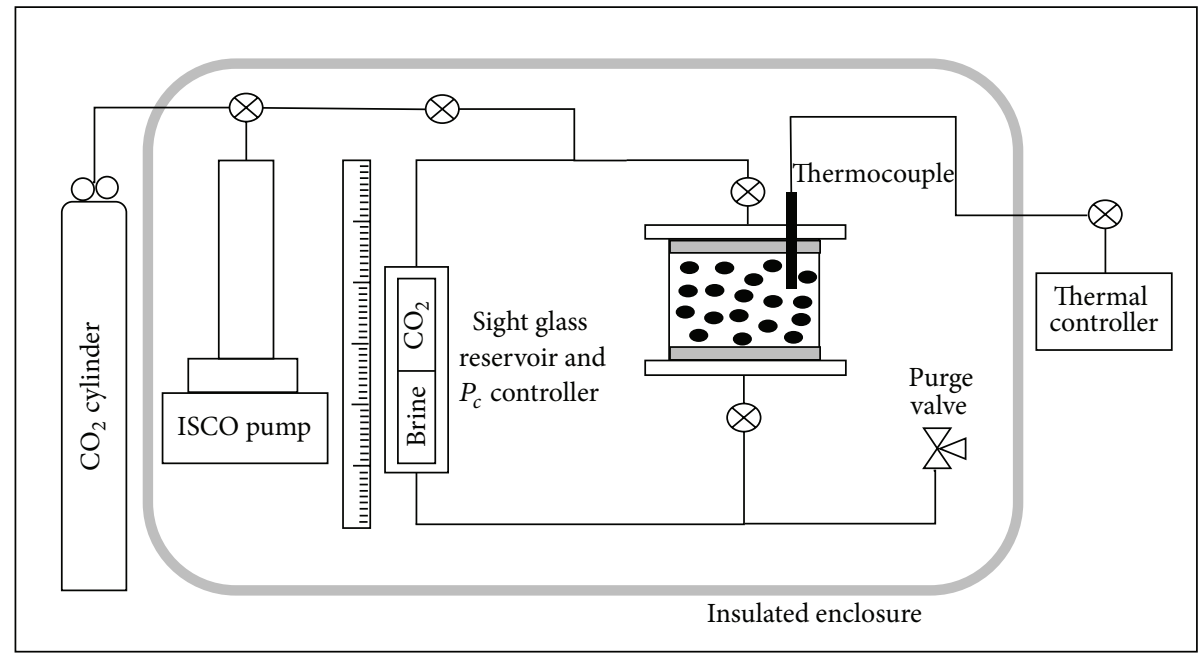

FIGURE 1: Experimental setup for capillary pressure-water saturation curve test.

TABLE 1: Fluid-dependent system properties related to our experimental conditions (Jung and Wan [31]; Bachu and Bennion [35]; Kestin et al. [58]; Fenghour et al. [59]).

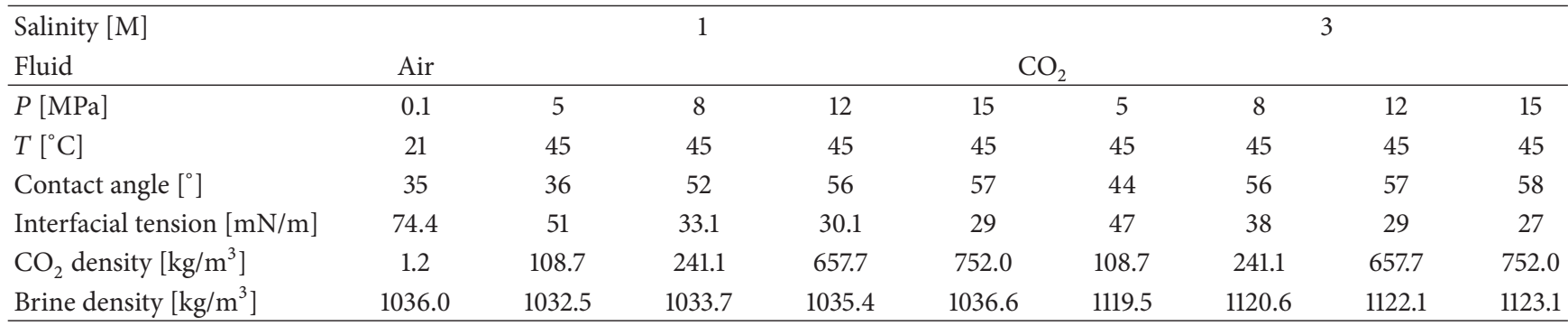

the sand pack in chamber that allows equilibration to zero capillary pressure $\left(P_{c}=0\right)$. Drainage curves were obtained by moving the water- $\mathrm{CO}_{2}$ interface in the capillary pressure regulator successively downward to lower depth, $h$, which is the elevation head difference between the surface of the sand pack and water- $\mathrm{CO}_{2}$ interface in the capillary pressure regulator. The outflow volumes from sand pack were measured using the capillary pressure regulator [61]. After obtaining the drainage curves, rewetting (or imbibition) curves were obtained by moving water- $\mathrm{CO}_{2}$ interface in the capillary pressure regulator successively upward [61]. As the elevation head difference, $h$, decreased during imbibition process, inflow water volume into the sand pack was measured using transparent capillary pressure regulator [note: the elevation head difference in this study can be controlled up to $\sim 2 \mathrm{~m}$, which implies that the capillary pressure can be up to $\sim$ $15 \mathrm{kPa}$ when temperature and pressure are $45^{\circ} \mathrm{C}$ and $8 \mathrm{MPa}$, resp.; thus, this method is adapted only to high permeable sand]. The capillary pressure induced by the regulator can be calculated using the following equation: $P_{c}=(\Delta \rho) \times h \times g$, where $\Delta \rho$ is the density difference between $\mathrm{CO}_{2}$ and brine (Table 1 ), $h$ is the elevation head difference, and $g$ is the gravitational acceleration.

Experimental system was connected to the high-pressure pump (Teledyne ISCO, $500 \mathrm{HP}$ ) so as to control the constant pressure of the closing system (Figure 1). The chamber was instrumented with a pressure transducer (OMEGA PX309) and a thermocouple (T-type, copper-constantan). Heating tapes surrounding the chamber with heat gun and heatinglight were used to maintain the chamber temperature $\left(\sim 45^{\circ} \mathrm{C}\right)$ with PID (proportional-integral-derivative) controller (Cole Parmer, EW-89000-10). The entire system was located in an insulating box. The variables tested in this study were pressure $(0.1$ to $15 \mathrm{MPa})$ and brine salinity $(1$ and $3 \mathrm{M} \mathrm{NaCl})$, while constant temperature was maintained $\left(\sim 45^{\circ} \mathrm{C}\right)$ (Table 1$)$.

\section{Results and Analyses}

Figure 2 shows the capillary pressure-water saturation curve in air-brine displacement at $0.1 \mathrm{MPa}$ air pressure that shows the consistency with the published data [56]. It implies that our experimental system is valid to measure the capillary pressure- $\left(P_{c^{-}}\right)$water saturation $\left(S_{w}\right)$ curve. Figures 3 and 4 show all experimental results obtained from this study using $1 \mathrm{M}$ and $3 \mathrm{M} \mathrm{NaCl}$ brine, respectively. $\mathrm{CO}_{2}$ pressure has the range of $5 \mathrm{MPa}$ to $15 \mathrm{MPa}$.

\subsection{Pressure Effect on Capillary Pressure-Water Saturation} Curve. Figures 3 and 4 represent the relations between capillary pressure $\left(P_{c}\right)$ and water saturation $\left(S_{w}\right)$ for different pressure and brine salinity conditions. $P_{c}-S_{w}$ relations shown in Figures 3 and 4 directly reflect the experimental procedure 


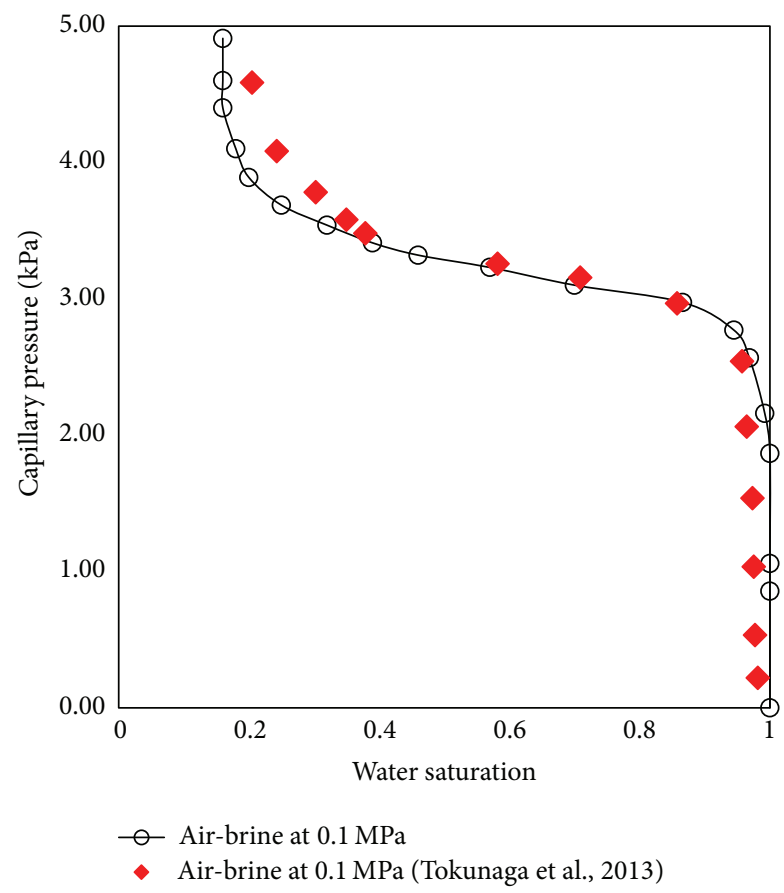

(a)

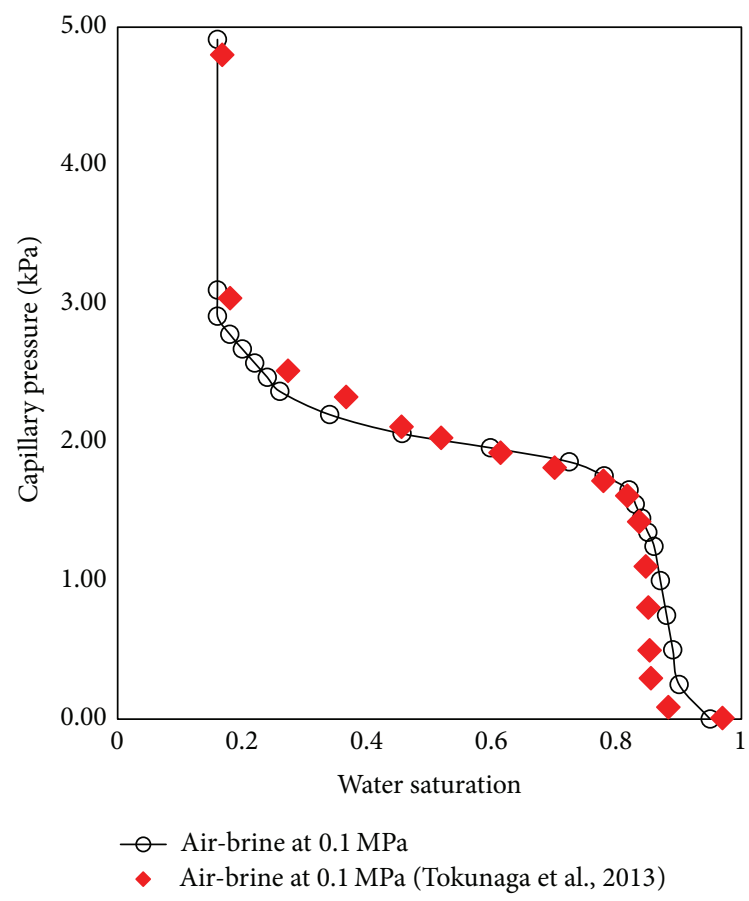

(b)

FIgURE 2: Capillary pressure-water saturation curve using the air-brine at $0.1 \mathrm{MPa}$ pressure, $1 \mathrm{M} \mathrm{NaCl}$. (a) Drainage and (b) imbibition.

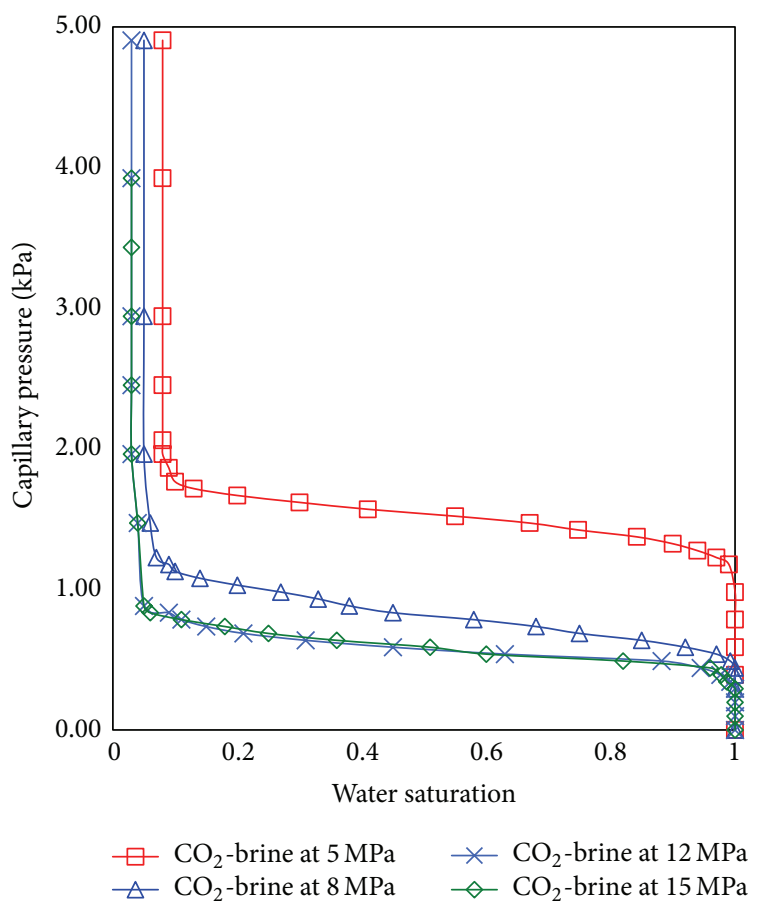

(a)

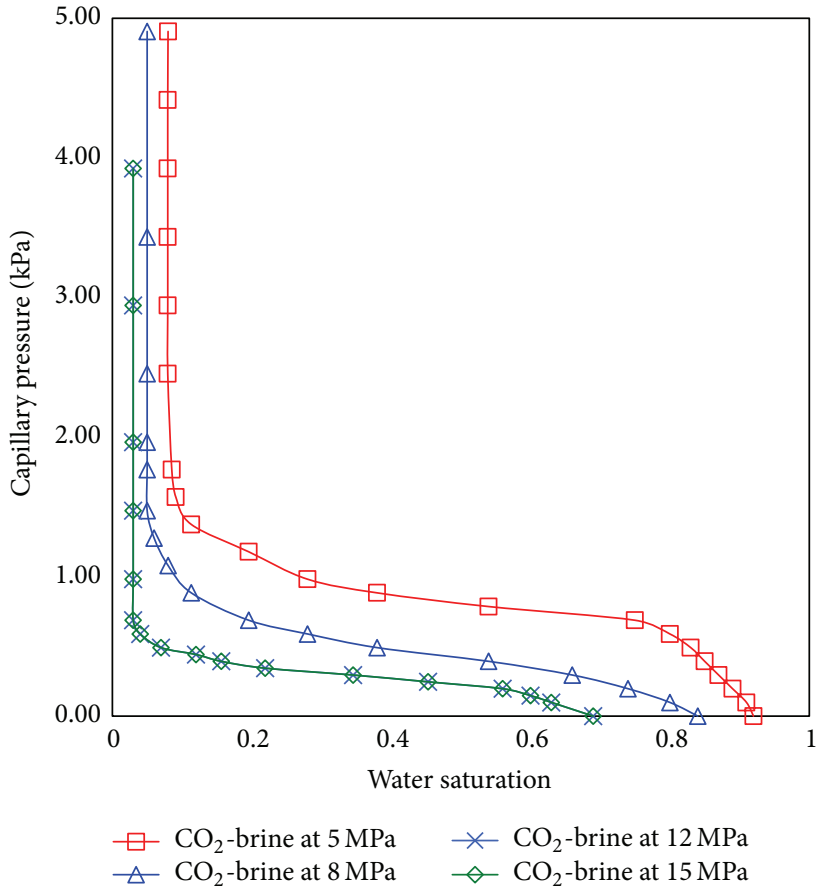

(b)

FIgURE 3: Capillary pressure-water saturation curve of $\mathrm{CO}_{2}$-brine at $1 \mathrm{M} \mathrm{NaCl}$. (a) Drainage and (b) imbibition.

involved in the control of the capillary pressure $\left(P_{c}\right)$ using the capillary pressure regulator. Uncertainties in average capillary pressure $\left(P_{c}\right)$ and water saturation $\left(S_{w}\right)$ of the sample are $\sim 10 \mathrm{~Pa}$ and $\sim 0.015$, respectively, considering the resolution of capillary pressure regulator. In both Figures 3 and 4, the results show that as $\mathrm{CO}_{2}$ pressure increases from $5 \mathrm{MPa}$ to $12 \mathrm{MPa}$ at $45^{\circ} \mathrm{C}$ temperature: generally (1) capillary pressurewater saturation curves shift to lower capillary pressure $\left(P_{c}\right)$ values associated with any given water saturation $\left(S_{w}\right)$ values; (2) capillary $\mathrm{CO}_{2}$ entry pressure $\left(P_{o}\right)$ decreases; (3) 


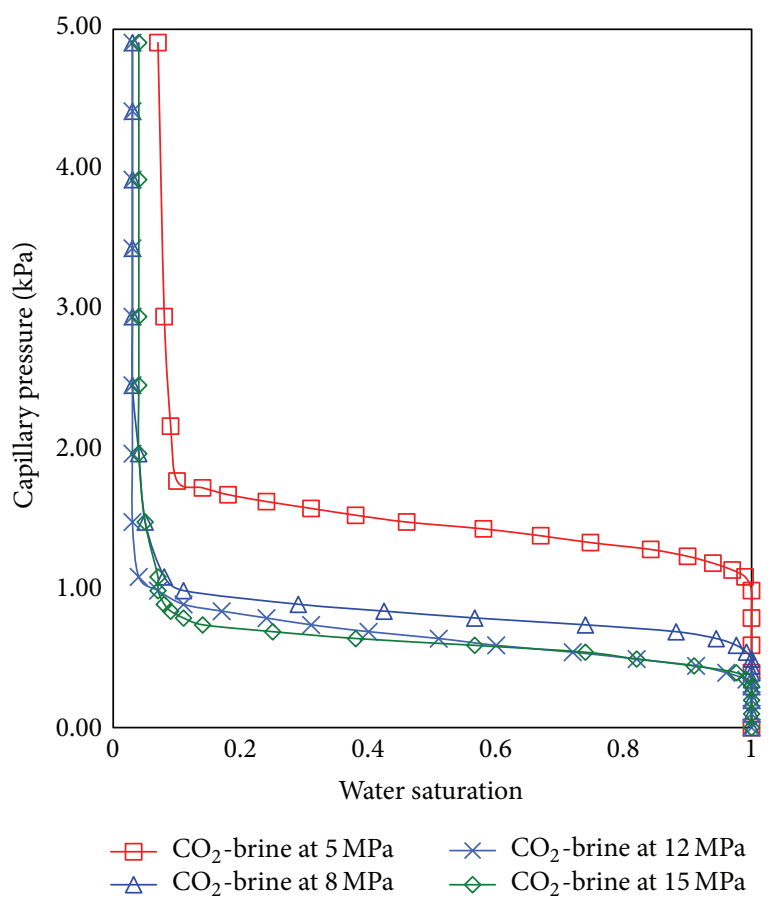

(a)

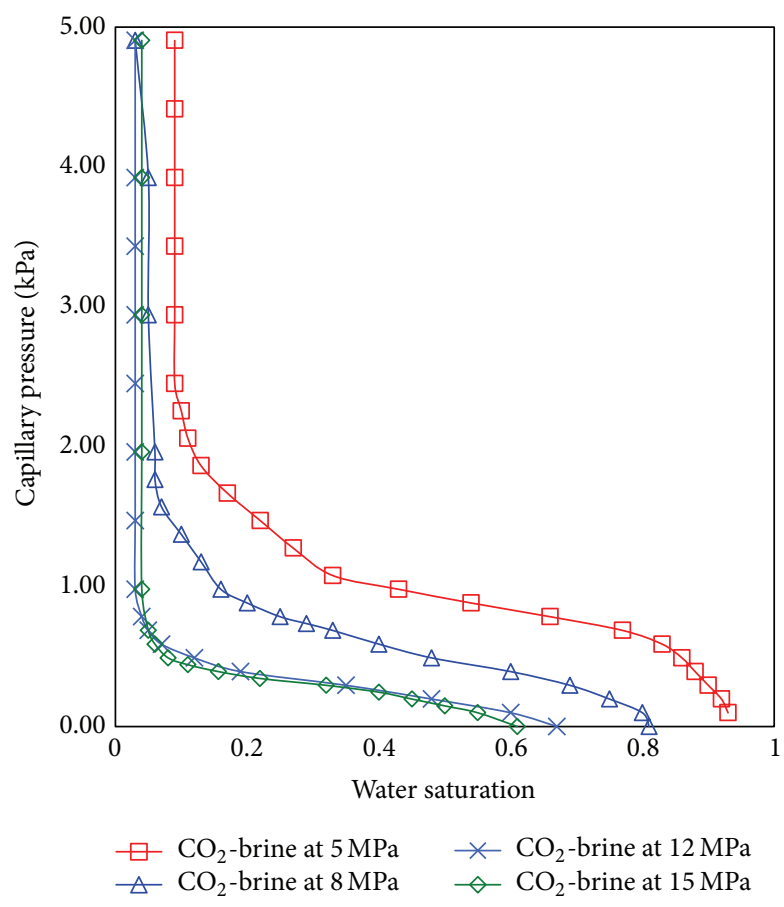

(b)

FIGURE 4: Capillary pressure-water saturation curve of $\mathrm{CO}_{2}$-brine at $3 \mathrm{M} \mathrm{NaCl}$. (a) Drainage and (b) imbibition.

residual brine saturation $\left(S_{r}\right)$ decreases after the drainage process; and (4) residual $\mathrm{CO}_{2}$ saturation $\left(S_{r, \mathrm{CO}_{2}}\right)$ increases after completing the imbibition process. However, capillary pressure-water saturation curves between $12 \mathrm{MPa}$ and $15 \mathrm{MPa}$ $\mathrm{CO}_{2}$ pressures relatively appeared similar.

Published data show that contact angle steeply increases in line with pressure from $7 \mathrm{MPa}$ to $10 \mathrm{MPa}$ and remains relatively constant until $25 \mathrm{MPa}$ [31]. Also, contact angle increases with brine salinity up to $5 \mathrm{M} \mathrm{NaCl}$ [31]. However, interfacial tension decreases in line with increased $\mathrm{CO}_{2}$ pressure and varies only within a small range of $20-35 \mathrm{mN} / \mathrm{m}$ at GCS relevant pressure and temperature conditions [29, $33,35]$. Table 1 shows the published data of contact angle and interfacial tension at various pressure and temperature conditions used in this study. Thus, as $\mathrm{CO}_{2}$ pressure increases from $5 \mathrm{MPa}$ to $12 \mathrm{MPa}$, contact angle increases and interfacial tension decreases, which causes the capillary $\mathrm{CO}_{2}$ entry pressure to decrease and capillary pressure-water saturation curves to shift to lower values at any given water saturation. Also, minor changes of contact angle and interfacial tension in the range of $12 \mathrm{MPa}$ to $15 \mathrm{MPa}$ have influence on relatively similar capillary pressure-water saturation curves in Figures 3 and 4 . It implies that the different capillary pressurewater saturation curves in GCS conditions depend on the variation of contact angle and interfacial tension according to increased pressure. Also, published data show that contact angle and interfacial tension remain constant when pressure is more than $10 \mathrm{MPa}[29,31,33,35]$. Thus, capillary pressurewater saturation curves at $10 \mathrm{MPa} \mathrm{CO}_{2}$ pressure conditions or higher are expected to be similar to the results at $12 \mathrm{MPa}$ in this study.

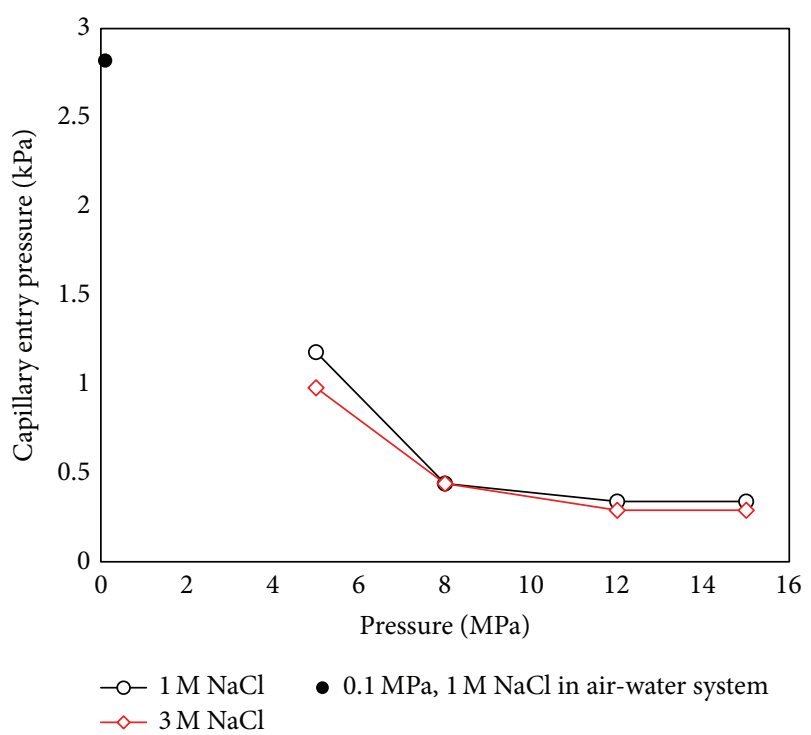

FIGURE 5: Capillary air (or $\mathrm{CO}_{2}$ ) entry pressure changes depending on increased pressure. Black filled circle represents $0.1 \mathrm{MPa}, 1 \mathrm{M}$ $\mathrm{NaCl}$ using air-water system. Empty circle and diamond represent $1 \mathrm{M}$ and $3 \mathrm{M} \mathrm{NaCl}$ using $\mathrm{CO}_{2}$-water system, respectively.

3.2. Brine Salinity Effect on Capillary Pressure-Water Saturation Curve. Figure 4 shows that general trend of capillary pressure-water saturation curves at $3 \mathrm{M} \mathrm{NaCl}$ is similar to $1 \mathrm{M} \mathrm{NaCl}$ in Figure 3. Figure 5 shows the capillary $\mathrm{CO}_{2}$ entry pressure changes at $1 \mathrm{M}$ and $3 \mathrm{M} \mathrm{NaCl}$ brine salinity resulting from increased pressure. The results show that (1) all capillary 


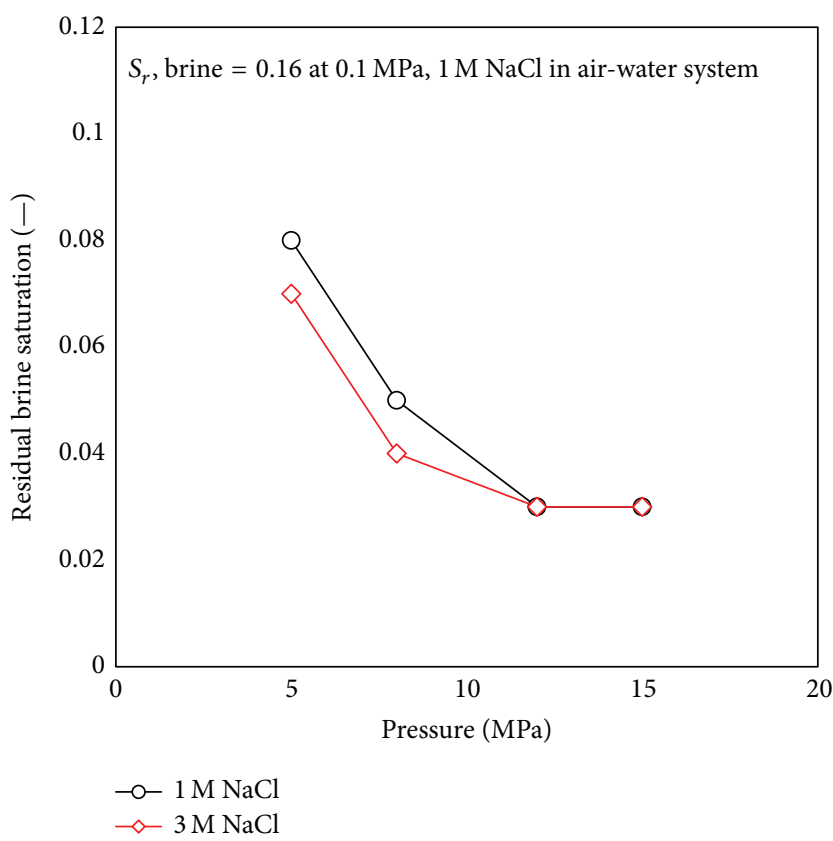

(a)

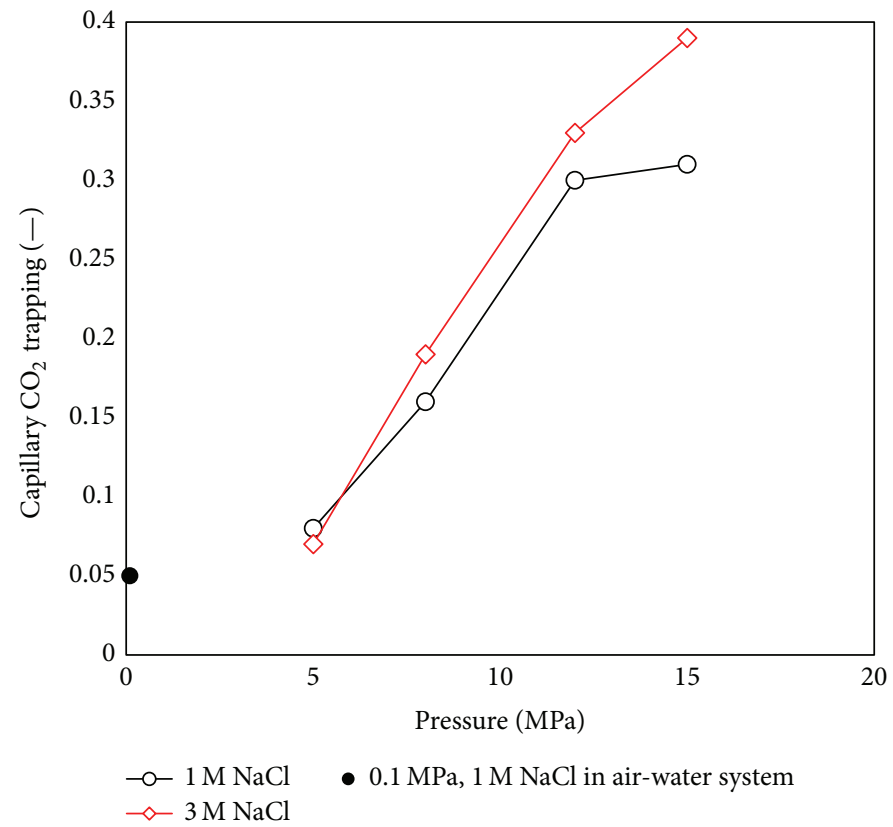

(b)

FIgURE 6: Residual brine and $\mathrm{CO}_{2}$ saturation. (a) Residual brine saturation after drainage process and (b) capillary $\mathrm{CO}_{2}$ trapping after imbibition process.

$\mathrm{CO}_{2}$ entry pressures (i.e., $0.29 \mathrm{kPa}$ to $1.18 \mathrm{kPa}$ at $1 \mathrm{M} \mathrm{NaCl}$ ) are much lower than capillary air entry pressure at $0.1 \mathrm{MPa}$ atmospheric pressure (i.e., $2.82 \mathrm{kPa}$ at $1 \mathrm{M} \mathrm{NaCl}$ ), (2) capillary $\mathrm{CO}_{2}$ entry pressure decreases while the pressure increased from $5 \mathrm{MPa}$ to $12 \mathrm{MPa}$ and remains constant until $15 \mathrm{MPa}$, and (3) capillary $\mathrm{CO}_{2}$ entry pressure is lower at $3 \mathrm{M} \mathrm{NaCl}$ than $1 \mathrm{M} \mathrm{NaCl}$. Generally, as the brine salinity increases, contact angle increases up to $5 \mathrm{M} \mathrm{NaCl}$ [31], while interfacial tension decreases $[29,33,35]$. Table 1 includes all contact angle and interfacial tension at the various pressure and temperature conditions used in this study. For example, at the pressure $5 \mathrm{MPa}$, as brine salinity increases from $1 \mathrm{M}$ to $3 \mathrm{M} \mathrm{NaCl}$ and contact angle increases from $36^{\circ}$ to $44^{\circ}$, while interfacial tension decreases from $51 \mathrm{mN} / \mathrm{m}$ to $47 \mathrm{mN} / \mathrm{m}$ (Table 1). Also, in the range of $8 \mathrm{MPa}$ to $15 \mathrm{MPa}$, increased contact angle and decreased interfacial tension are observed with increased brine salinity from $1 \mathrm{M}$ to $3 \mathrm{M} \mathrm{NaCl}$, which causes the capillary $\mathrm{CO}_{2}$ entry pressure to decrease in Figure 5 [note that increased contact angle and decreased interfacial tension are not significant from $8 \mathrm{MPa}$ to $15 \mathrm{MPa}$.

Jung and Wan [31] showed that the contact angle increased with brine salinity almost linearly, with a net increase of $19.6^{\circ} \pm 2.1^{\circ}$ from $0 \mathrm{M}$ to $5.0 \mathrm{M} \mathrm{NaCl}$ with $\mathrm{CO}_{2}$ pressure range of $0.1 \mathrm{MPa}$ to $20 \mathrm{MPa}$ at $45^{\circ} \mathrm{C}$. It implies that more capillary $\mathrm{CO}_{2}$ entry pressure decrease is expected with the increased brine salinity unitl $5 \mathrm{M} \mathrm{NaCl}$.

3.3. Residual Brine Saturation and Capillary $\mathrm{CO}_{2}$ Trapping in GCS. Figure 6(a) shows the residual water saturation $\left(S_{r}\right)$ with increased pressure at $1 \mathrm{M}$ and $3 \mathrm{M} \mathrm{NaCl}$ brine salinity. The results show that (1) the residual water saturation $\left(S_{r}\right)$ value in air-water measurement is $\sim 0.16$ at $1 \mathrm{M} \mathrm{NaCl}$ which is consistent with the range in published data $\left(0.14 \leq S_{r} \leq\right.$ 0.16, Gittins et al. [62]; Schroth et al. [63]), which verifies our experimental system; (2) residual water saturation values $\left(S_{r}\right)$ after completing the drainage process generally decrease due to increased $\mathrm{CO}_{2}$ pressure from $5 \mathrm{MPa}$ to $12 \mathrm{MPa}$ and remain constant until $15 \mathrm{MPa}$. Contact angle increases steeply as pressure increases from $7 \mathrm{MPa}$ to $10 \mathrm{MPa}$ and remains relatively constant until $25 \mathrm{MPa}$ [31]. Table 1 includes the contact angle used in this study. It implies that sand pack becomes more hydrophobic under the higher $\mathrm{CO}_{2}$ pressure within the range of $5 \mathrm{MPa}$ to $12 \mathrm{MPa}$, which has an influence on less residual water saturation in sand pack with increased pressure up to $12 \mathrm{MPa}$ in Figure 6(a). Also, similar contact angles in the range of $12 \mathrm{MPa}$ to $15 \mathrm{MPa} \mathrm{CO}_{2}$ pressure (i.e., $56^{\circ}-57^{\circ}$ at $1 \mathrm{M} \mathrm{NaCl}$ ) cause the residual water saturation to remain relatively constant with the range of $12 \mathrm{MPa}$ to $15 \mathrm{MPa}$, and (3) residual water saturation values $\left(S_{r}\right)$ decrease with brine salinity from $1 \mathrm{M}$ to $3 \mathrm{M} \mathrm{NaCl}$. Increased contact angle with brine salinity from $1 \mathrm{M}$ to $3 \mathrm{M} \mathrm{NaCl}$ in Table 1 implies that sand pack also becomes more hydrophobic under higher brine salinity, which causes the residual water saturation to decrease with increased brine salinity from $1 \mathrm{M}$ to $3 \mathrm{M} \mathrm{NaCl}$ in the range of $5 \mathrm{MPa}$ to $12 \mathrm{MPa}$. However, small variation of contact angles at 12 15 MPa has an influence on relatively constant residual water saturation (i.e., $56^{\circ}-57^{\circ}$ at $1 \mathrm{M} \mathrm{NaCl}$ and $57^{\circ}-58^{\circ}$ at $3 \mathrm{M} \mathrm{NaCl}$ ) which implies that residual water saturation at $12 \mathrm{MPa}$ or higher is not affected by brine salinity due to similar contact angles. Tokunaga et al. [56], showed that silica surface became more hydrophobic according to increased $\mathrm{CO}_{2}$ exposure time. Also, Wan et al. [49] observed that contact angle on silica surface increases with exposure time to $\mathrm{CO}_{2}$. Even though the results by Wan et al. [49] 


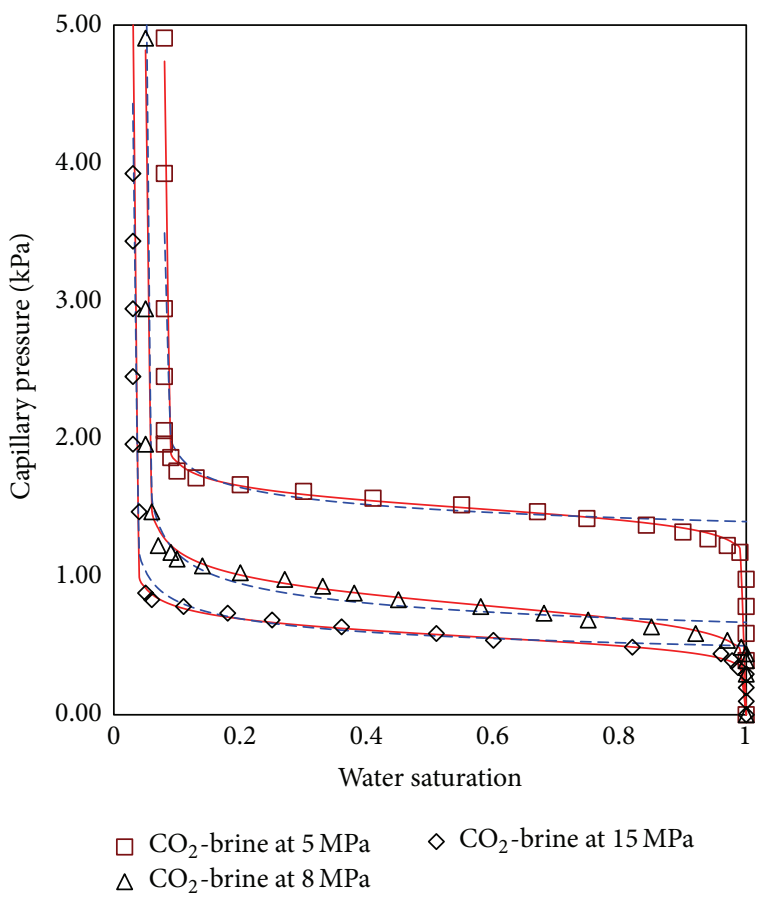

(a)

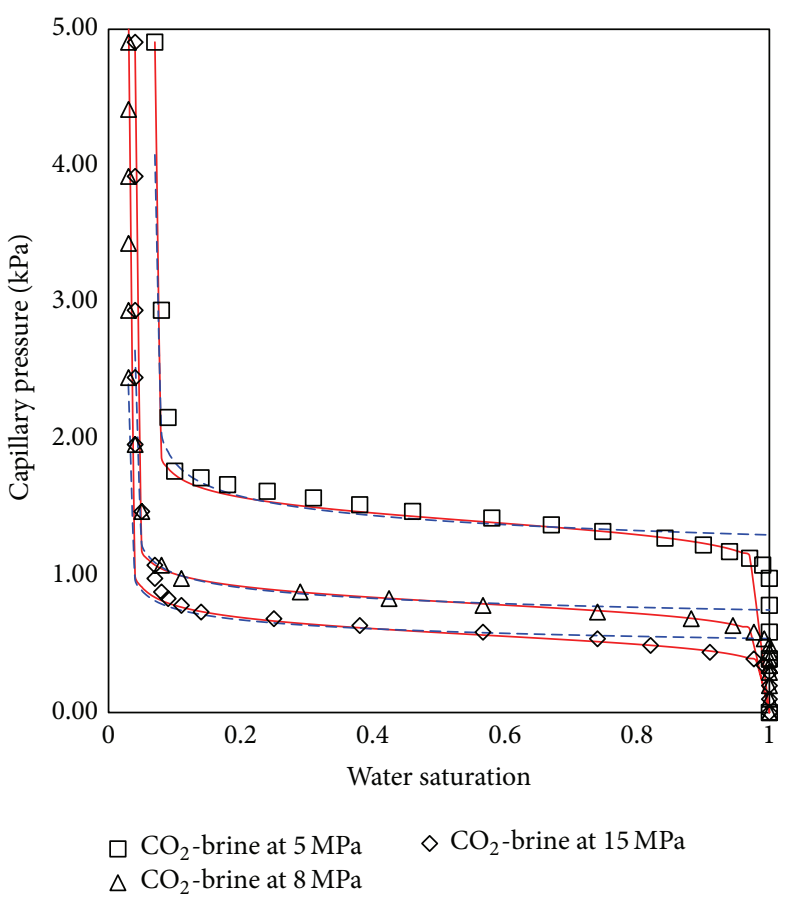

(b)

FIGURE 7: Capillary pressure-water saturation curves based on experiments and theoretical models. (a) Drainage and (b) imbibition.

and Tokunaga et al. [56], were obtained from the short-term laboratory tests, it is expected that residual water saturation can be increased with a long-term in situ $\mathrm{CO}_{2}$ injection into the field because the increased $\mathrm{CO}_{2}$ exposure time causes the mineral surface to be more hydrophobic.

Figure 6(b) shows the residual $\mathrm{CO}_{2}$ saturation in pores after imbibition process, which can be considered as capillary $\mathrm{CO}_{2}$ trapping capacity in geological $\mathrm{CO}_{2}$ storage. Capillary trapping is the result of hysteresis by drainage and imbibition process during/after $\mathrm{CO}_{2}$ injection in the porous medium. $\mathrm{CO}_{2}$ injection in geological $\mathrm{CO}_{2}$ storage generates the drainage process that displaces the resident brine with injected $\mathrm{CO}_{2}$ in pores. After $\mathrm{CO}_{2}$ injection is completed, the brine returns to the storage site, which generates an imbibition process and causes a certain amount of $\mathrm{CO}_{2}$ to be trapped by capillary pressure $[64,65]$. For imbibition curves, while residual brine saturation in the air-brine displacement returns back to $95 \%$ at zero capillary pressure, residual $\mathrm{CO}_{2}$ saturation increases in the $\mathrm{CO}_{2}$-brine displacement with increased $\mathrm{CO}_{2}$ pressure, which is consistent with the previous results by Tokunaga et al. [56] [note that it is not consistent with the trends of residual oil saturation during the desaturation; residual oil saturation decreases when the wettability becomes less [66]]. For example, 5\% residual $\mathrm{CO}_{2}$ saturation at $0.1 \mathrm{MPa}$ air-brine system with $1 \mathrm{M} \mathrm{NaCl}$ increases up to $31 \%$ at $15 \mathrm{MPa} \mathrm{CO}_{2}$ pressure and $1 \mathrm{M} \mathrm{NaCl}$, indicating that more capillary $\mathrm{CO}_{2}$ trapping can be expected in geological $\mathrm{CO}_{2}$ storage after the completion of imbibition process than the estimate from the air-brine displacement tests. General trends in Figure 6(b) show that (1) capillary $\mathrm{CO}_{2}$ trapping increases with $\mathrm{CO}_{2}$ pressure and (2) more capillary $\mathrm{CO}_{2}$ trapping is observed with $3 \mathrm{M} \mathrm{NaCl}$ than $1 \mathrm{M}$ $\mathrm{NaCl}$, which implies that higher capillary $\mathrm{CO}_{2}$ trapping in the long-term period field tests can be expected compared to the results from the laboratory test.

\section{Discussion}

4.1. Theoretical Models. Figure 7 presents the capillary pressure-water saturation curves using theoretical models such as both van Genuchten [25] and Brooks and Corey [24] models, which have a good consistency with experimental results. Capillary $\mathrm{CO}_{2}$ entry pressure obtained from theoretical models decreases with increased pressure the same as experimental results and the curve slope decreases slightly in $\mathrm{CO}_{2}$-brine displacement comparing to the air-brine displacement, which cause $m$ - and $\lambda$-values to decrease with increased pressure up to $8 \mathrm{MPa}$ (Table 2). $m$-value in the airbrine displacement is 0.96 in this study, which is consistent with published data ( $m=0.90$ for hygiene sandstone, van Genuchten [25]) [note that hygiene sandstone is one of the sandstone types in the north-northwestern area in USA]. $m$ value reflects the sensitivity of capillarity increase over the change of water saturation $\Delta P_{c} / \Delta S_{w}$, which decreases in a $\mathrm{CO}_{2}$-brine displacement with the increased pressure up to $8 \mathrm{MPa}$ and remains relatively constant in the range of $8 \mathrm{MPa}$ to $15 \mathrm{MPa}$. It implies that the capillarity increases slower as brine drainage progresses in sediments with higher pressures. For example, at $5 \mathrm{MPa} \mathrm{CO}$ pressure and $1.0 \mathrm{M} \mathrm{NaCl}$, when capillary pressure is $\sim 1.86 \mathrm{kPa}$ that is only $\sim 0.36 \mathrm{kPa}$ higher than capillary $\mathrm{CO}_{2}$ entry pressure (i.e., $\sim 1.5 \mathrm{kPa}$ ), brine less than $9 \%$ (i.e., $S_{r}<\sim 0.09$ ) only remains in pores. As the $\mathrm{CO}_{2}$ 
TABLE 2: $m$ - and $\lambda$-values obtained from van Genuchten and Brooks-Corey models.

\begin{tabular}{|c|c|c|c|c|c|}
\hline \multirow[t]{2}{*}{ Gas } & \multirow[t]{2}{*}{ Pressure [Mpa] } & \multicolumn{2}{|c|}{$\begin{array}{c}\text { van Genuchten } \\
m \text {-values }\end{array}$} & \multicolumn{2}{|c|}{$\begin{array}{c}\text { Brooks-Corey } \\
\lambda \text {-values }\end{array}$} \\
\hline & & $1 \mathrm{M} \mathrm{NaCl}$ & $3 \mathrm{M} \mathrm{NaCl}$ & $1 \mathrm{M} \mathrm{NaCl}$ & $3 \mathrm{M} \mathrm{NaCl}$ \\
\hline Air & 0.1 & 0.96 & - & 16.67 & - \\
\hline \multirow{4}{*}{$\mathrm{CO}_{2}$} & 5 & 0.95 & 0.94 & 12.50 & 12.50 \\
\hline & 8 & 0.88 & 0.92 & 5.26 & 9.09 \\
\hline & 12 & 0.9 & 0.86 & 5.26 & 7.14 \\
\hline & 15 & 0.89 & 0.89 & 5.26 & 7.69 \\
\hline
\end{tabular}

pressure increases, the residual brine saturation decreases with the low increase of capillary pressure after $\mathrm{CO}_{2}$ injection (Figure 7).

Besides, the results show that $\lambda$-values decrease with increased pressure (Table 2). It also implies that the capillary pressure increases less as brine drainage processes in sediments with higher pressures, which is consistent with $m$ values. $\lambda$-value in the air-brine displacement is $\sim 12.5$, which is within the range of published data $(\lambda=3.42$ for hydrophilic sand with $0^{\circ}$ contact angle and $\lambda=20.0$ for hydrophobic sand with $88^{\circ}$ contact angle, Shokri et al. [67]; Brooks and Corey [24]). Viewing the contact angle $\sim 38^{\circ}$ on silica sand in this study, $\lambda$-value is considered reasonable.

4.2. Capillary-Scaled Capillary Pressure-Water Saturation Curves. Capillary scaling factor, which is a dimensionless number, has been used to predict the capillary pressure-water saturation curves in porous media considering contact angle and interfacial tension [60, 68-70]. Capillary scaling factor $\Pi_{c}$ based on Young-Laplace equation (3) is as follows [56] [note that pore radius $R$ is relatively similar in all sand packs due to same particles size distribution and porosity; thus, it was disregarded in capillary scaling factor]:

$$
\Pi_{c}=\frac{1}{\sigma \times \cos \theta}
$$

Figure 8 shows the scaled capillary $\mathrm{CO}_{2}$ entry pressure that is estimated considering the capillary scaling factor and capillary entry pressure (Table 1) (i.e., scaled capillary $\mathrm{CO}_{2}$ entry pressure $[1 / \mathrm{mm}]=P_{0} \times \Pi_{c}$ ). While the scaled capillary $\mathrm{CO}_{2}$ entry pressure in a $\mathrm{CO}_{2}$-brine displacement shows relatively similar values, the scaled value in the air-brine displacement is much higher than $\mathrm{CO}_{2}$-brine displacement. This inconsistency can be considered as (1) the uncertainty of wettability alteration in GCS. While it is clear that contact angle increases at pressure-temperature conditions relevant to GCS, the extents of wettability alteration have not been fully understood and show the inconsistency among the published data [28-31], which has an influence on the distinct scaled capillary $\mathrm{CO}_{2}$ entry pressure; (2) the published data show a wide range of contact angle in pores compared to the constant contact angle on a flat surface [32]. Kim et al. [32] observed that contact angles in pores using twodimensional microfluidic model have a wide range of contact angle in GCS, which can hinder the scaled capillary $\mathrm{CO}_{2}$

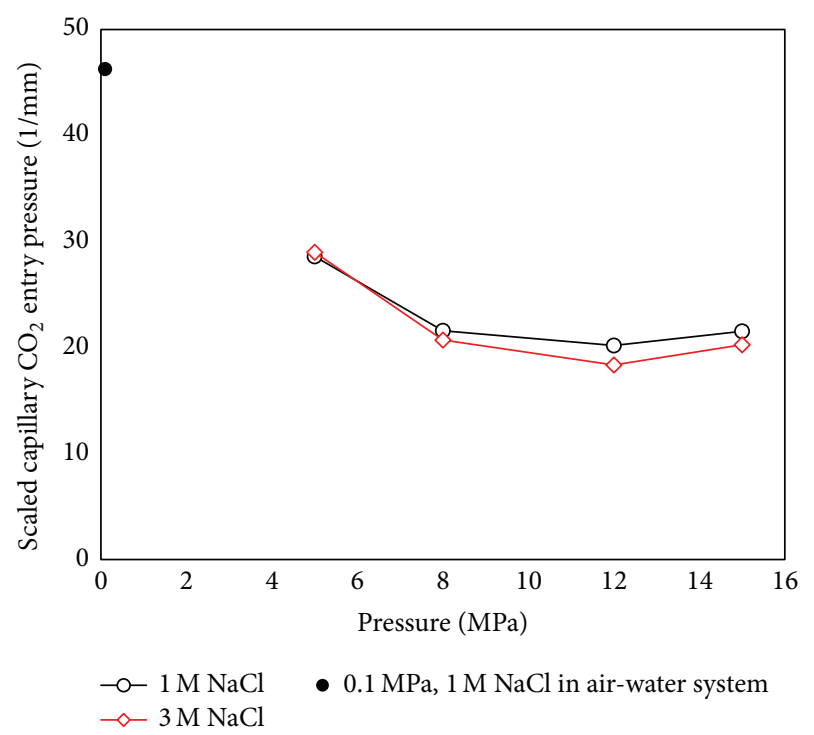

FIGURE 8: Scaled capillary $\mathrm{CO}_{2}$ entry pressure with increased pressure using $1 \mathrm{M}$ and $3 \mathrm{M} \mathrm{NaCl}$.

entry pressure to become identical; and (3) receding-contact angles are considered for the scaled capillary $\mathrm{CO}_{2}$ entry pressure, which is usually less than equilibrium contact angle [71]. In case of air-brine displacement, all receding-contact angles are constant. Thus, the impacts of contact angle on the scaled capillary $\mathrm{CO}_{2}$ entry pressure may be disregarded [60, 68-70]. However, a wide range of receding-contact angles in GCS should be strictly considered in the scaled capillary $\mathrm{CO}_{2}$ entry pressure. Thus, the difference between equilibrium- and receding-contact angles has an influence on inconsistency of scaled capillary $\mathrm{CO}_{2}$ entry pressure in this study (Figure 8).

\section{Conclusions}

The capillary pressure-water saturation curves in a homogeneous silica sand pack are examined at various pressure and brine salinity conditions relevant to GCS, which are then compared with the values obtained from two theoretical models such as Brooks-Corey and van Genuchten models. The capillary pressure-water saturation curves using the theoretical models such as Brooks-Corey and van Genuchten models show a good consistency with experimental results, which provide the information on sensitivity of capillarity.

Generally, the results show that as the $\mathrm{CO}_{2}$ pressure in geological $\mathrm{CO}_{2}$ storage increases, (1) capillary $\mathrm{CO}_{2}$ entry pressure $P_{o}$ decreases; (2) capillary pressure-water saturation curves shift to lower values at the given water saturation $S_{w}$; (3) after completing the drainage process, residual water saturation $S_{r}$ decreases; (4) after imbibition process, capillary $\mathrm{CO}_{2}$ trapping $S_{r, \mathrm{CO}_{2}}$ (or residual $\mathrm{CO}_{2}$ saturation) increases; (5) the sensitivity of capillarity increase over the change of water saturation decreases; and (6) fitting parameters in theoretical models, $m$ - and $\lambda$-values, are decreased slightly.

Also, as brine salinity increases from $1 \mathrm{M}$ to $3 \mathrm{M} \mathrm{NaCl}$, (1) capillary pressure-water saturation shifts to lower values at given water saturation $S_{w}$, and capillary $\mathrm{CO}_{2}$ entry pressure 
$P_{o}$ decreases due to increased contact angle and decreased interfacial tension and (2) residual water saturation decreases, but capillary $\mathrm{CO}_{2}$ trapping increases because silica surface becomes more hydrophobic because of the reaction with injected $\mathrm{CO}_{2}$.

The results show that $\mathrm{CO}_{2}$ pressure and brine salinity in GCS have an influence on the capillary pressure-water saturation curves due to varying contact angle and interfacial tension. Thus, capillary scaling factor is considered to predict the capillary pressure-water saturation curves. However, the results show that the scaled capillary $\mathrm{CO}_{2}$ entry pressure in geological $\mathrm{CO}_{2}$ sequestration is inconsistent with atmospheric conditions due to the lack of wettability information. Further exploration of wettability alteration in GCS is required to predict the capillary pressure-water saturation curves at various conditions which are relevant to geological $\mathrm{CO}_{2}$ sequestration.

\section{Competing Interests}

The authors declare that they have no competing interests.

\section{Acknowledgments}

This research was supported by Basic Science Research Program through the National Research Foundation of Korea (NRF) funded by the Ministry of Science, ICT, and Future Planning (Grant no. 2013R1A2A2A01068174). Also, this work was supported by FIER (the Fund for Innovative Engineering Research-Round V) grant award.

\section{References}

[1] C. Tsouris, D. S. Aaron, and K. A. Williams, "Is carbon capture and storage really needed?" Environmental Science and Technology, vol. 44, no. 11, pp. 4042-4045, 2010.

[2] X. Xie and M. J. Economides, "The impact of carbon geological sequestration," in Proceedings of the SPE Americas E\&P Environmental \& Safety Conference, San Antonio, Tex, USA, March 2009.

[3] S. M. Benson and T. Surles, "Carbon dioxide capture and storage: an overview with emphasis on capture and storage in deep geological formations," Proceedings of the IEEE, vol. 94, no. 10, pp. 1795-1805, 2006.

[4] Q. Li, Z. S. Wu, and X. C. Li, "Prediction of $\mathrm{CO}_{2}$ leakage during sequestration into marine sedimentary strata," Energy Conversion and Management, vol. 50, no. 3, pp. 503-509, 2009.

[5] C. M. White, D. H. Smith, K. L. Jones et al., "Sequestration of carbon dioxide in coal with enhanced coalbed methane recovery-a review," Energy and Fuels, vol. 19, no. 3, pp. 659724, 2005.

[6] IPCC, "IPCC special report on carbon dioxide capture and storage," in Working Group III of the Intergovernmental Panel on Climate Change, B. Metz, O. Davidson, H. C. de Coninck, M. Loos, and L. A. Meyer, Eds., p. 442, Cambridge University Press, Cambridge, UK, 2005.

[7] C. M. White, B. R. Strazisar, E. J. Granite, J. S. Hoffman, and H. W. Pennline, "Separation and capture of $\mathrm{CO}_{2}$ from large stationary sources and sequestration in geological formationscoalbeds and deep saline aquifers," Journal of the Air \& Waste Management Association, vol. 53, no. 6, pp. 645-715, 2003.

[8] M. Akbarabadi and M. Piri, "Relative permeability hysteresis and capillary trapping characteristics of supercritical $\mathrm{CO}_{2} /$ brine systems: An experimental study at reservoir conditions," Advances in Water Resources, vol. 52, pp. 190-206, 2013.

[9] S. Bachu, D. Bonijoly, J. Bradshaw et al., " $\mathrm{CO}_{2}$ storage capacity estimation: methodology and gaps," International Journal of Greenhouse Gas Control, vol. 1, no. 4, pp. 430-443, 2007.

[10] D. B. Bennion and S. Bachu, "Drainage and imbibition relative permeability relationships for supercritical $\mathrm{CO}_{2} /$ brine and $\mathrm{H}_{2} \mathrm{~S} /$ brine systems in intergranular sandstone, carbonate, shale, and anhydrite rocks," SPE Reservoir Evaluation and Engineering, vol. 11, no. 3, pp. 487-496, 2008.

[11] S. M. Benson and D. R. Cole, " $\mathrm{CO}_{2}$ sequestration in deep sedimentary formations," Elements, vol. 4, no. 5, pp. 325-331, 2008.

[12] N. C. Brady and R. R. Weil, Elements of the Nature and Properties of Soils, Pearson Prentice Hall, Upper Saddle River, NJ, USA, 2010.

[13] S. Assouline, "A model for soil relative hydraulic conductivity based on the water retention characteristic curve," Water Resources Research, vol. 37, no. 2, pp. 265-271, 2001.

[14] G. S. Campbell, "A simple method for determining unsaturated conductivity from moisture retention data," Soil Science, vol. 117, no. 6, pp. 311-314, 1974.

[15] U. Fischer and M. A. Celia, "Prediction of relative and absolute permeabilities for gas and water from soil water retention curves using a pore-scale network model," Water Resources Research, vol. 35, no. 4, pp. 1089-1100, 1999.

[16] Y. Mualem, "Hydraulic conductivity of unsaturated soils: prediction and formulas," Agronomy, vol. 9, pp. 799-823, 1986.

[17] T. Vogel and M. Cislerova, "On the reliability of unsaturated hydraulic conductivity calculated from the moisture retention curve," Transport in Porous Media, vol. 3, no. 1, pp. 1-15, 1988.

[18] D. G. Fredlund, A. Xing, M. D. Fredlund, and S. L. Barbour, "The relationship of the unsaturated soil shear strength to the soil-water characteristic curve," Canadian Geotechnical Journal, vol. 33, no. 3, pp. 440-448, 1996.

[19] A. L. Öberg and G. Sällfors, "Determination of shear strength parameters of unsaturated silts and sands based on the water retention curve," Geotechnical Testing Journal, vol. 20, no. 1, pp. 40-48, 1997.

[20] S. K. Vanapalli, D. G. Fredlund, D. E. Pufahl, and A. W. Clifton, "Model for the prediction of shear strength with respect to soil suction," Canadian Geotechnical Journal, vol. 33, no. 3, pp. 379392, 1996.

[21] P. Delage, M. D. Howat, and Y. J. Cui, "The relationship between suction and swelling properties in a heavily compacted unsaturated clay," Engineering Geology, vol. 50, no. 1-2, pp. 31-48, 1998.

[22] A. Gens and E. E. Alonso, "A framework for the behaviour of unsaturated expansive clays," Canadian Geotechnical Journal, vol. 29, no. 6, pp. 1013-1032, 1992.

[23] A. Pedarla, A. J. Puppala, L. R. Hoyos, S. K. Vanapalli, and C. Zapata, Unsaturated Soils: Research and Applications, vol. 1, Springer, Berlin, Germany, 2012.

[24] R. Brooks and A. Corey, Hydraulic Properties of Porous Media, vol. 3, Colorado State University Hydrology Papers, Fort Collins, Colo, USA, 1964. 
[25] M. T. van Genuchten, "A closed-form equation for predicting the hydraulic conductivity of unsaturated soils," Soil Science Society of America Journal, vol. 44, pp. 892-898, 1980.

[26] G. Pijaudier-Cabot and J.-M. Pereira, Geomechanics in CO Storage Facilities, John Wiley \& Sons, New York, NY, USA, 2013.

[27] D. Broseta, N. Tonnet, and V. Shah, "Are rocks still water-wet in the presence of dense $\mathrm{CO}_{2}$ or $\mathrm{H}_{2} \mathrm{~S}$ ?" Geofluids, vol. 12, no. 4, pp. 280-294, 2012.

[28] P. K. Bikkina, "Contact angle measurements of $\mathrm{CO}_{2}$-waterquartz/calcite systems in the perspective of carbon sequestration," International Journal of Greenhouse Gas Control, vol. 5, no. 5, pp. 1259-1271, 2011.

[29] P. Chiquet, J.-L. Daridon, D. Broseta, and S. Thibeau, " $\mathrm{CO}_{2} /$ water interfacial tensions under pressure and temperature conditions of $\mathrm{CO}_{2}$ geological storage," Energy Conversion and Management, vol. 48, no. 3, pp. 736-744, 2007.

[30] J. L. Dickson, G. Gupta, T. S. Horozov, B. P. Binks, and K. P. Johnston, "Wetting phenomena at the $\mathrm{CO}_{2}$ /water/glass interface," Langmuir, vol. 22, no. 5, pp. 2161-2170, 2006.

[31] J.-W. Jung and J. Wan, "Supercritical $\mathrm{CO}_{2}$ and ionic strength effects on wettability of silica surfaces: equilibrium contact angle measurements," Energy and Fuels, vol. 26, no. 9, pp. 60536059, 2012.

[32] Y. Kim, J. Wan, T. J. Kneafsey, and T. K. Tokunaga, "Dewetting of silica surfaces upon reactions with supercritical $\mathrm{CO}_{2}$ and brine: pore-scale studies in micromodels," Environmental Science and Technology, vol. 46, no. 7, pp. 4228-4235, 2012.

[33] C. Chalbaud, M. Robin, J.-M. Lombard, F. Martin, P. Egermann, and H. Bertin, "Interfacial tension measurements and wettability evaluation for geological $\mathrm{CO}_{2}$ storage," Advances in Water Resources, vol. 32, no. 1, pp. 98-109, 2009.

[34] C. A. Aggelopoulos, M. Robin, E. Perfetti, and O. Vizika, " $\mathrm{CO}_{2} / \mathrm{CaCl}_{2}$ Solution interfacial tensions under $\mathrm{CO}_{2}$ geological storage conditions: influence of cation valence on interfacial tension," Water Resources Research, vol. 51, pp. 197-216, 2010.

[35] S. Bachu and D. B. Bennion, "Interfacial tension between $\mathrm{CO}_{2}$, freshwater, and brine in the range of pressure from (2 to 27) $\mathrm{MPa}$, temperature from $(20 \text { to } 125)^{\circ} \mathrm{C}$, and water salinity from (0to334 000) $\mathrm{mg} \bullet \mathrm{L}^{-1}$," Journal of Chemical and Engineering Data, vol. 54, no. 3, pp. 765-775, 2009.

[36] V. Shah, D. Broseta, G. Mouronval, and F. Montel, "Water/acid gas interfacial tensions and their impact on acid gas geological storage," International Journal of Greenhouse Gas Control, vol. 2, no. 4, pp. 594-604, 2008.

[37] C. Duchateau and D. Broseta, "A simple method for determining brine-gas interfacial tensions," Advances in Water Resources, vol. 42, pp. 30-36, 2012.

[38] D. Chiquet and D. Broseta, "Capillary alteration of shaly caprocks by carbon dioxide," in Proceedings of the SPE Europec/ EAGE Annual Conference, SPE 94183, Madrid, Spain, June 2005.

[39] J. S. Loring, C. J. Thompson, Z. Wang et al., "In situ infrared spectroscopic study of forsterite carbonation in wet supercritical $\mathrm{CO}_{2}$," Environmental Science and Technology, vol. 45, no. 14, pp. 6204-6210, 2011.

[40] H. Shao, J. R. Ray, and Y.-S. Jun, "Effects of salinity and the extent of water on supercritical $\mathrm{CO}_{2}$-induced phlogopite dissolution and secondary mineral formation," Environmental Science and Technology, vol. 45, no. 4, pp. 1737-1743, 2011.

[41] T. K. Tokunaga, "DLVO-based estimates of adsorbed water film thicknesses in geologic $\mathrm{CO}_{2}$ reservoirs," Langmuir, vol. 28, no. 21, pp. 8001-8009, 2012.
[42] G. Vigil, Z. Xu, S. Steinberg, and J. Israelachvile, "Interactions of silica surfaces," Journal of Colloid and Interface Science, vol. 165, no. 2, pp. 367-385, 1994.

[43] A. Vishnyakov, Y. Shen, and M. S. Tomassone, "Interactions of silica nanoparticles in supercritical carbon dioxide," Journal of Chemical Physics, vol. 129, no. 17, Article ID 174704, 2008.

[44] D. Y. Yang, Y. G. Gu, and P. Tontiwachwuthikul, "Wettability determination of the reservoir brine-reservoir rock system with dissolution of $\mathrm{CO}_{2}$ at high pressures and elevated temperatures," Energy and Fuels, vol. 22, no. 1, pp. 504-509, 2008.

[45] S. Saraji, L. Goual, M. Piri, and H. Plancher, "Wettability of supercritical carbon dioxide/water/quartz systems: simultaneous measurement of contact angle and interfacial tension at reservoir conditions," Langmuir, vol. 29, no. 23, pp. 6856-6866, 2013.

[46] S. Iglauer, A. Salamah, M. Sarmadivaleh, K. Liu, and C. Phan, "Contamination of silica surfaces: Impact on water- $\mathrm{CO}_{2}$-quartz and glass contact angle measurements," International Journal of Greenhouse Gas Control, vol. 22, pp. 325-328, 2014.

[47] A. Al-Yaseri, M. Sarmadivaleh, A. Saeedi, M. Lebedev, A. Barifcani, and S. Iglauer, " $\mathrm{N}_{2}+\mathrm{CO}_{2}+\mathrm{Nacl}$ brine interfacial tensions and contact angles on quartz at $\mathrm{CO}_{2}$ storage site conditions in the Gippsland basin, Victoria/Australia," Journal of Petroleum Science and Engineering, vol. 129, pp. 58-62, 2015.

[48] M. Sarmadivaleh, A. Z. Al-Yaseri, and S. Iglauer, "Influence of temperature and pressure on quartz-water- $\mathrm{CO}_{2}$ contact angle and $\mathrm{CO}_{2}$-water interfacial tension," Journal of Colloid and Interface Science, vol. 441, pp. 59-64, 2015.

[49] J. Wan, Y. Kim, and T. K. Tokunaga, "Contact angle measurement ambiguity in supercritical $\mathrm{CO}_{2}$-water-mineral systems: mica as an example," International Journal of Greenhouse Gas Control, vol. 31, pp. 128-137, 2014.

[50] N. Shojai Kaveh, E. S. J. Rudolph, P. van Hemert, W. R. Rossen, and K.-H. Wolf, "Wettability evaluation of a $\mathrm{CO}_{2} /$ water/ bentheimer sandstone system: contact angle, dissolution, and bubble size," Energy and Fuels, vol. 28, no. 6, pp. 4002-4020, 2014.

[51] D. R. Palamara, T. Neeman, A. N. Golab, and A. Sheppard, "A statistical analysis of the effects of pressure, temperature and salinity on contact angles in $\mathrm{CO}_{2}$-brine-quartz systems," International Journal of Greenhouse Gas Control, vol. 42, pp. 516-524, 2015.

[52] S. C. M. Krevor, R. Pini, B. Li, and S. M. Benson, "Capillary heterogeneity trapping of $\mathrm{CO}_{2}$ in a sandstone rock at reservoir conditions," Geophysical Research Letters, vol. 38, no. 15, 2011.

[53] C. H. Pentland, R. El-Maghraby, S. Iglauer, and M. J. Blunt, "Measurements of the capillary trapping of super-critical carbon dioxide in Berea sandstone," Geophysical Research Letters, vol. 38, no. 6, Article ID L06401, 2011.

[54] R. Pini, S. C. M. Krevor, and S. M. Benson, "Capillary pressure and heterogeneity for the $\mathrm{CO}_{2}$ /water system in sandstone rocks at reservoir conditions," Advances in Water Resources, vol. 38, pp. 48-59, 2012.

[55] W.-J. Plug and J. Bruining, "Capillary pressure for the sand$\mathrm{CO}_{2}$-water system under various pressure conditions. Application to $\mathrm{CO}_{2}$ sequestration," Advances in Water Resources, vol. 30, no. 11, pp. 2339-2353, 2007.

[56] T. K. Tokunaga, J. Wan, J.-W. Jung, T. W. Kim, Y. Kim, and W. Dong, "Capillary pressure and saturation relations for supercritical $\mathrm{CO}_{2}$ and brine in sand: High-pressure $\mathrm{Pc}(\mathrm{Sw})$ controller/meter measurements and capillary scaling predictions," Water Resources Research, vol. 49, no. 8, pp. 4566-4579, 2013. 
[57] J.-C. Perrin and S. Benson, "An experimental study on the influence of sub-core scale heterogeneities on $\mathrm{CO}_{2}$ distribution in reservoir rocks," Transport in Porous Media, vol. 82, no. 1, pp. 93-109, 2010.

[58] J. Kestin, H. E. Khalifa, and R. Correia, "Table of the dynamic and kinematic viscosity of aqueous $\mathrm{NaCl}$ solution in the temperature range $20-150^{\circ} \mathrm{C}$ and the pressure range $0.1-35 \mathrm{Mpa}$," Journal of Physical and Chemical Reference Data, vol. 10, no. 1, pp. 71-88, 1981.

[59] A. Fenghour, W. A. Wakeham, and V. Vesovic, "The viscosity of carbon dioxide," Journal of Physical and Chemical Reference Data, vol. 27, no. 1, pp. 31-44, 1998.

[60] W. B. Haines, "Studies in the physical properties of soil. V. The hysteresis effect in capillary properties, and the modes of moisture distribution associated therewith," The Journal of Agricultural Science, vol. 20, pp. 97-116, 1930.

[61] T. K. Tokunaga, J. Wan, and K. R. Olson, "Saturation-matric potential relations in gravel," Water Resources Research, vol. 38, no. 10, pp. 321-327, 2002.

[62] P. Gittins, S. Iglauer, C. H. Pentland et al., "Nonwetting phase residual saturation in sand packs," Journal of Porous Media, vol. 13, no. 7, pp. 591-599, 2010.

[63] M. H. Schroth, J. D. Istok, S. J. Ahearn, and J. S. Selker, "Characterization of miller-similar silica sands for laboratory hydrologic studies," Soil Science Society of America Journal, vol. 60, no. 5, pp. 1331-1339, 1996.

[64] A. Kumar, R. Ozah, M. Noh et al., "Reservoir simulation of $\mathrm{CO}_{2}$ storage in deep saline aquifers," SPE Journal, vol. 10, no. 3, pp. 336-348, 2005.

[65] R. Juanes, E. J. Spiteri, F. M. Orr Jr., and M. J. Blunt, "Impact of relative permeability hysteresis on geological $\mathrm{CO}_{2}$ storage," Water Resources Research, vol. 42, no. 12, Article ID W12418, 2006.

[66] K. J. Humphry, B. Suijkerbuijk, H. A. van der Linde, and S. Masalmeh, "Impact of wettability on residual oil saturation and capillary desaturation curves," Petrophysics, vol. 55, no. 4, pp. 313-318, 2014, Proceedings of the International Symposium of the Society of Core Analysts.

[67] N. Shokri, P. Lehmann, and D. Or, "Characteristics of evaporation from partially wettable porous media," Water Resources Research, vol. 45, no. 2, Article ID W02415, 2009.

[68] M. C. Leverett, "Capillary behavior in porous solids," Transactions of the American Institute of Mining and Metallurgical Engineers, vol. 142, no. 1, pp. 152-169, 1941.

[69] E. E. Miller and R. D. Miller, "Physical theory for capillary flow phenomena," Journal of Applied Physics, vol. 27, no. 4, pp. 324332, 1956.

[70] W. Rose and W. Bruce, "Evaluation of capillary character in petroleum reservoir rock," Journal of Petroleum Technology, vol. 1, pp. 127-142, 1949.

[71] N. R. Morrow, "Effects of surface roughness on contact angle with special reference to petroleum recovery," Journal of Canadian Petroleum Technology, vol. 14, no. 4, pp. 42-53, 1975. 

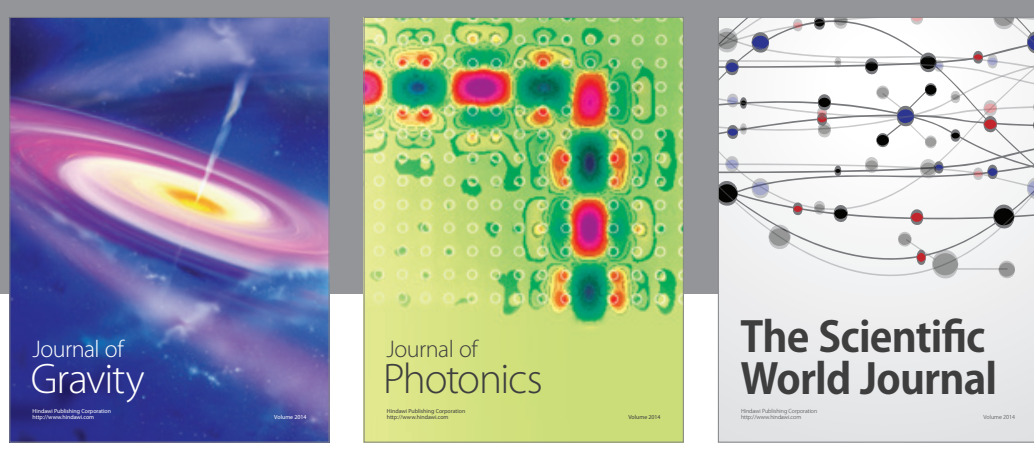

The Scientific World Journal
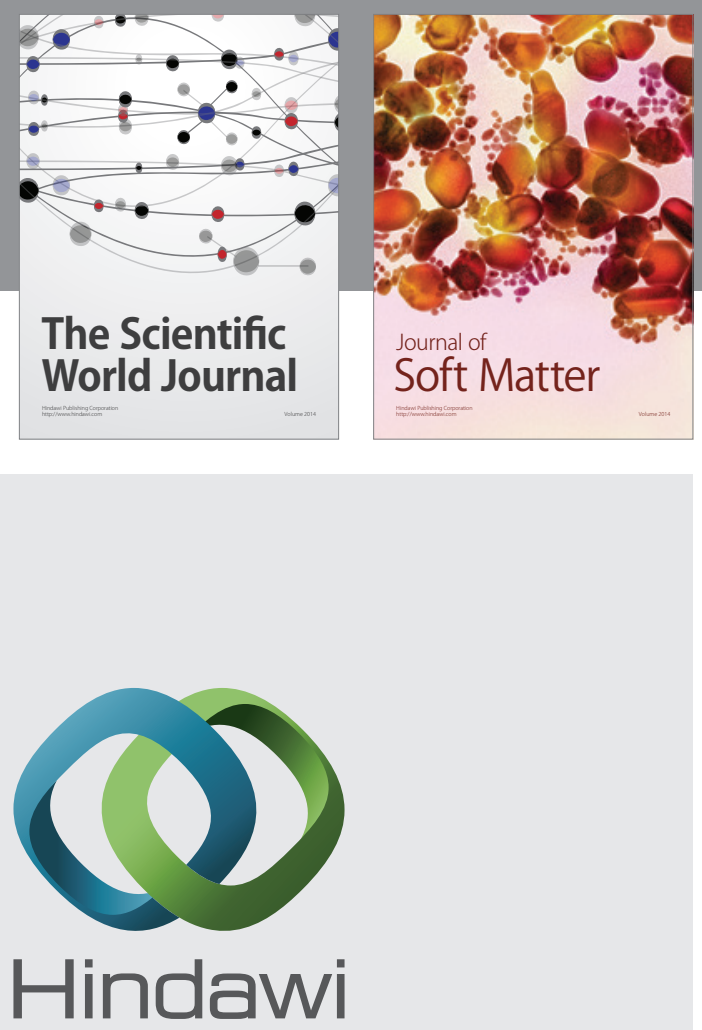

Submit your manuscripts at

http://www.hindawi.com

nternational Journal of

Statistical Mechanics
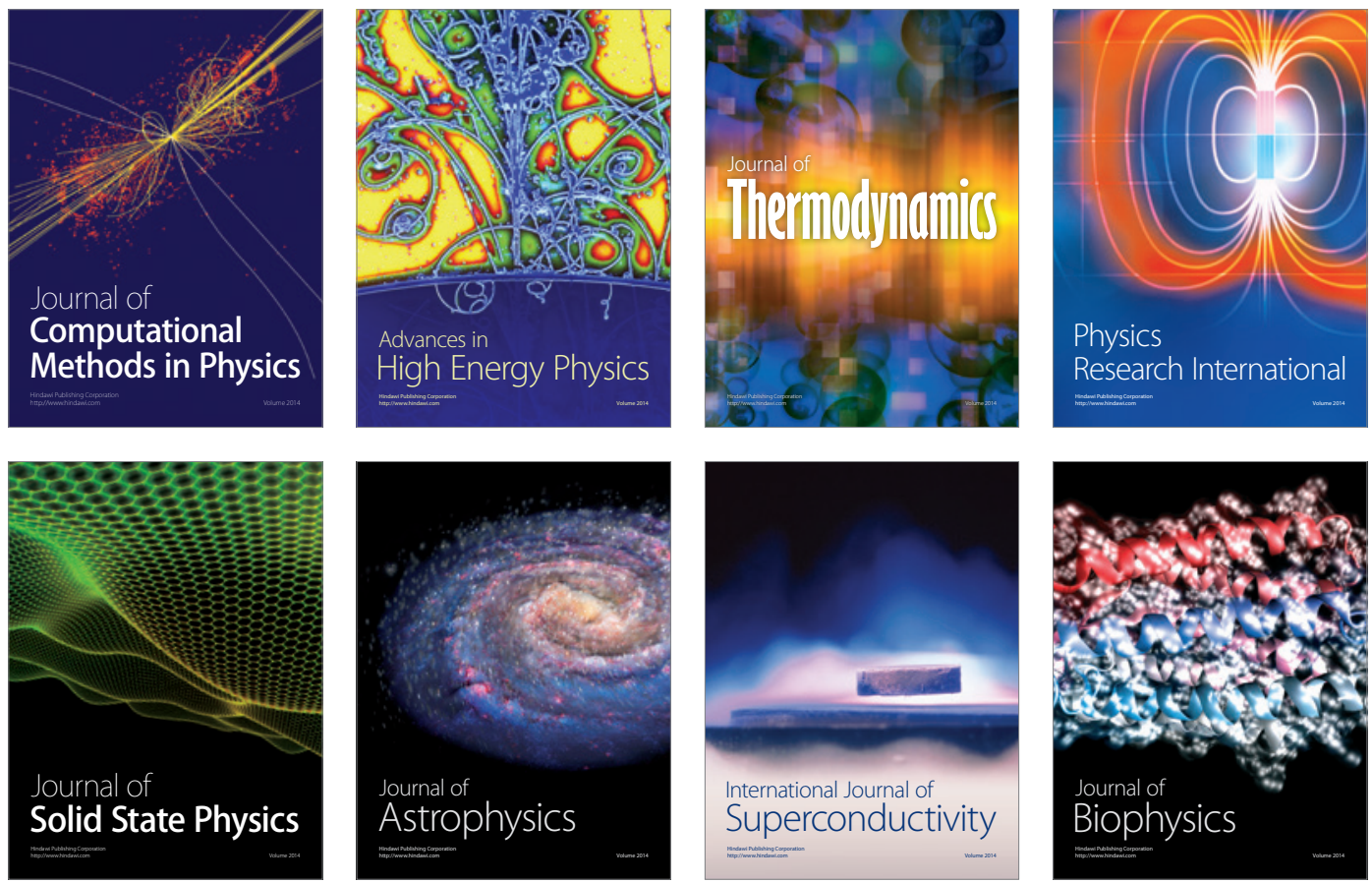
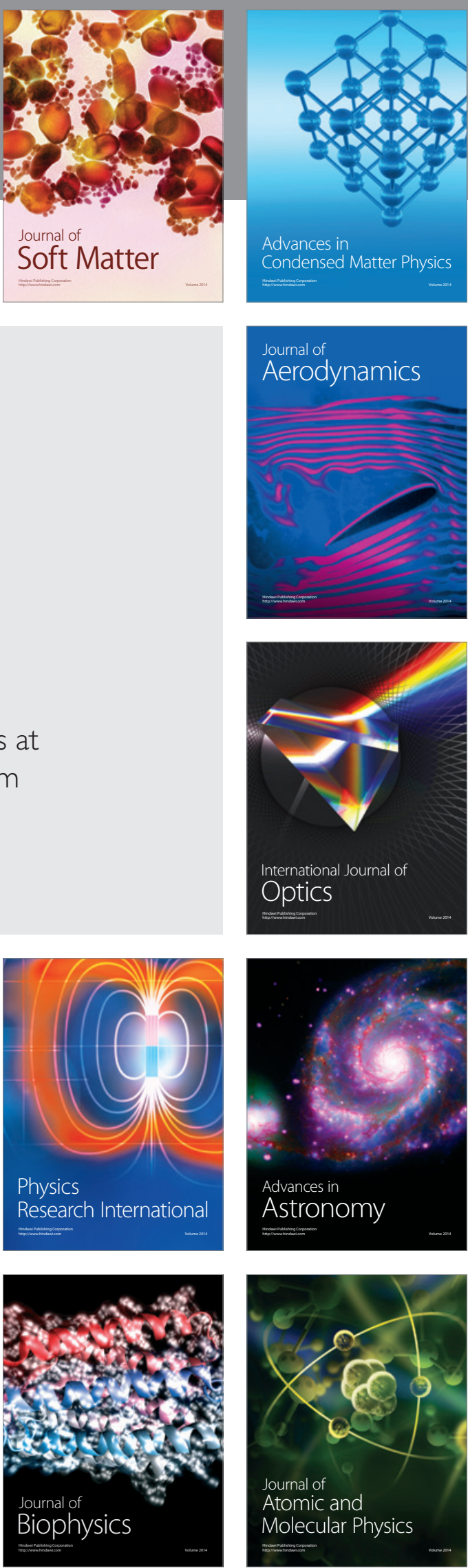